\title{
Lost Worlds
}




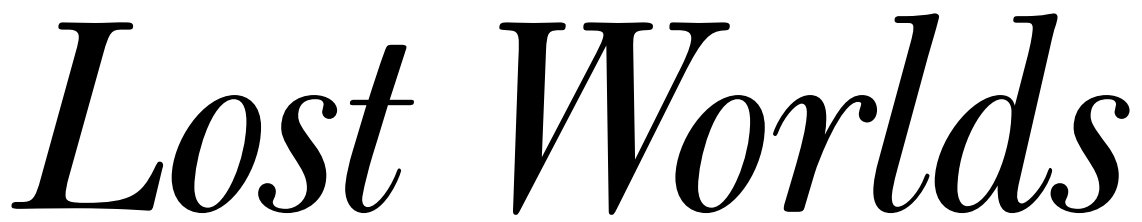

Bruce M. Beehler

Illustrations

by

John Anderton

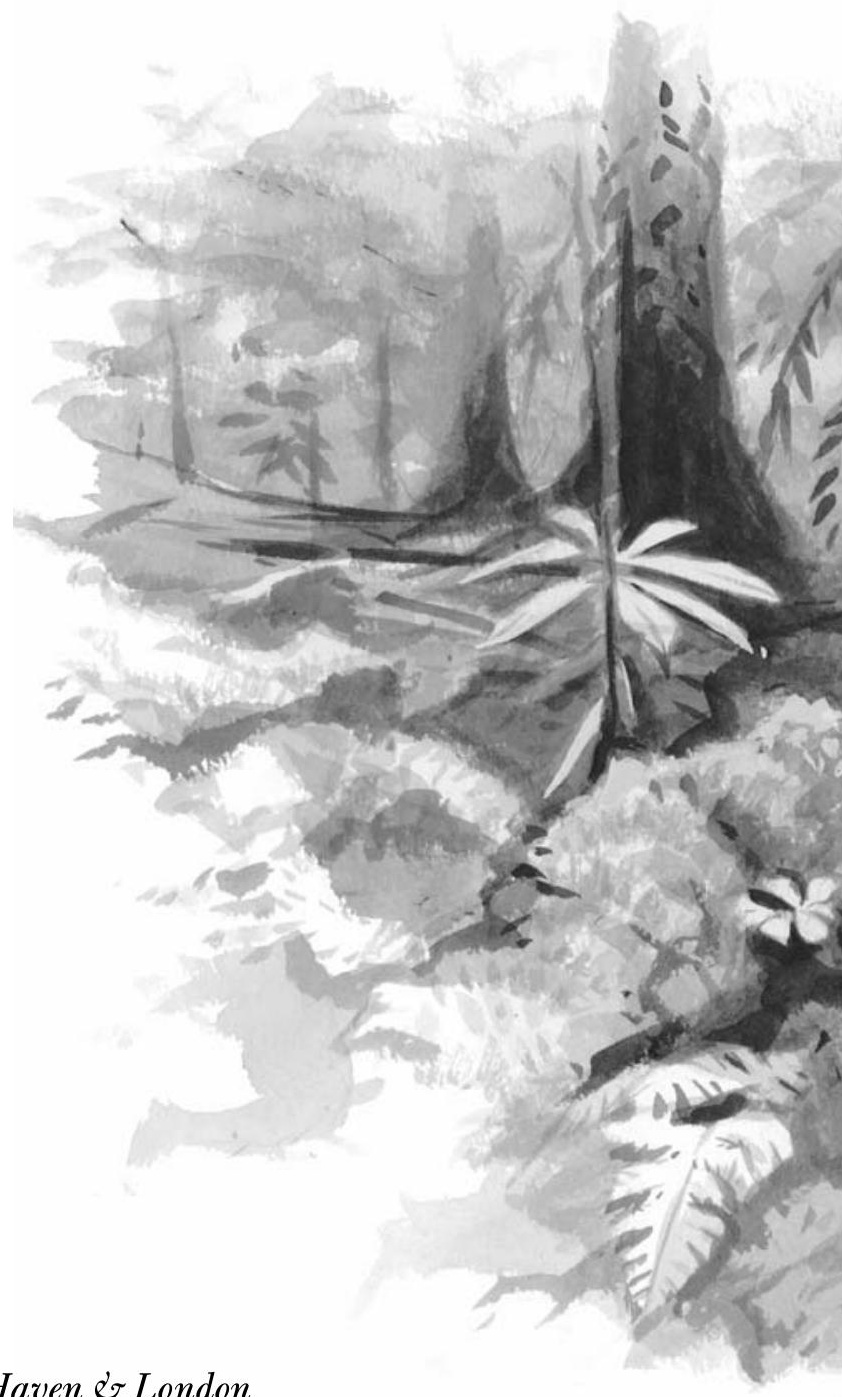

Yale University Press New Haven \& London 


\section{Adventures in the Tropical Rainforest}

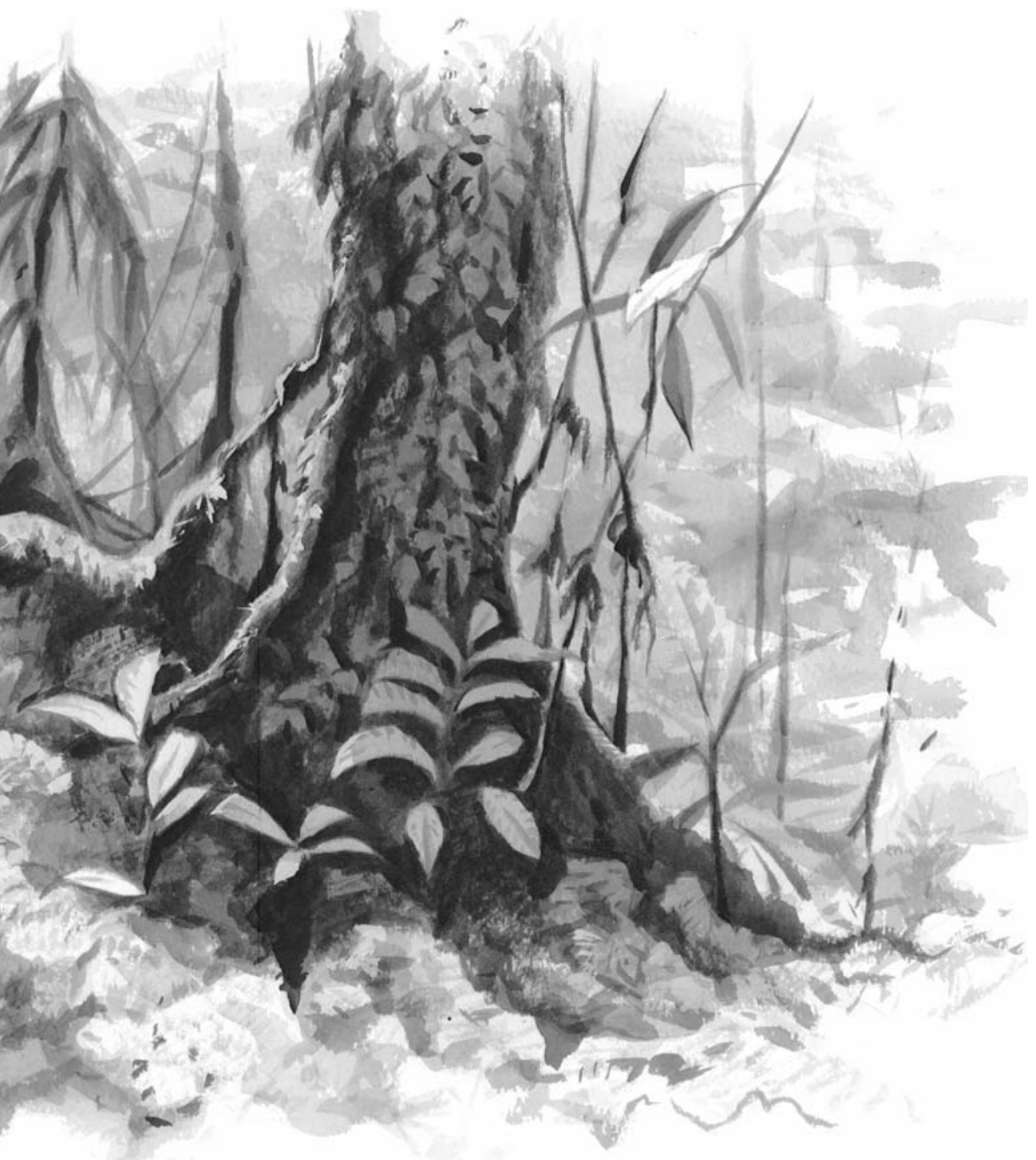


Published with assistance from the foundation established in memory of Philip Hamilton McMillan of the Class of 1894, Yale College.

\section{Copyright (C) 2008 by Yale University.}

Illustrations on title pages and chapter opening pages copyright (C) 2008 by John Anderton.

All rights reserved.

This book may not be reproduced, in whole or in part, including illustrations, in any form (beyond that copying permitted by Sections 107 and 108 of the U.S. Copyright Law and except by reviewers for the public press), without written permission from the publishers.

Designed by Sonia Shannon.

Set in Monotype Bulmer by Duke \& Company, Devon, Pennsylvania. Printed in the United States of America.

Library of Congress Cataloging-in-Publication Data

Beehler, Bruce McP.

Lost worlds : adventures in the tropical rainforest / Bruce M. Beehler.

p. $\mathrm{cm}$.

Includes bibliographical references and index.

ISBN 978-0-300-12228-2 (cloth : alk. paper) 1. Birds-Tropics.

2. Beehler, Bruce McP.-Travel. 3. Ornithologists-United States-Biography. 4. Naturalists-United States-Biography. I. Title.

QL695.5B44 2008

$$
508.315^{\prime} 20913-\mathrm{dc} 22 \quad 2007044560
$$

A catalogue record for this book is available from the British Library.

The paper in this book meets the guidelines for permanence and durability of the Committee on Production Guidelines for Book Longevity of the Council on Library Resources. 
To Garol, Grace, Andrew, and Cary who keep the home fires burning 
This page intentionally left blank 